\title{
Examining The Correlation Between Phubbing and Life Satisfaction in Adults During Covid-19 Pandemic
}

\section{Covid 19 Pandemisi Sürecinde Yetişkinlerde Phubbing ile Yaşam Doyumu} Arasındaki Illişkinin İncelenmesi

\author{
(D) Filiz POLAT ${ }^{1}$, (1) Fatma KARASU ${ }^{2}$ \\ ${ }^{1}$ Osmaniye University Faculty of Health Sciences, Department of Midwifery, Osmaniye, Turkey \\ ${ }^{2}$ Kilis 7 Aralık University, Yusuf Şerefoğlu Faculty of Health Sciences, Department of Nursing, Kilis, Turkey
}

\section{Abstract}

Objective: This study was carried out to investigate the correlation between the phubbing and life satisfaction in adult individuals in Turkey during the pandemic.

Method: The population of this descriptive study was composed of individuals over the age of 18 in Turkey. The study was carried out with 682 individuals between 15.02 .2021 and 15.03 .2021 by using the snowball sampling method, one of the improbable sampling methods. The data were collected using "Personal Information Form, Phubbing Scale, and Satisfaction With Life Scale".

Results: A negative and moderate correlation was found between Phubbing Scale and Satisfaction With Life Scale. It was determined that the phubbing levels of the participants were moderate and their life satisfaction were low.

Conclusion:A significant correlation was found between phubbing and life satisfaction. Nurses should provide individuals with positive health behaviors to prevent phone addiction during the covid-19 pandemic process.

Keywords: Phubbing, use of mobile phone, life satisfaction, Turkey

\section{$\ddot{\mathrm{O} z}$}

Amaç: Bu çalıșma pandemi sürecinde Türkiye'deki yetişkin bireylerde phubbing ile yașam doyumu arasındaki ilișkinin incelenmesi amacıyla yapılmıștır.

Yöntem: Betimleyici tipteki araştırmanın evrenini Türkiye'deki 18 yaş üzeri bireyler oluşturmuştur. Araştırma olassılıksız örnekleme yöntemlerinden kartopu örnekleme yöntemi kullanılarak 15.02.2021-15.03.2021 tarihleri arasında 682 birey ile yürütülmüștür. Veriler "Kișisel Bilgi Formu, Phubbing Ölçeği ve Yaşam Doyumu Ölçeği” kullanılarak toplanmıștır.

Bulgular: Phubbing Ölçeği ile Yaşamdan Memnuniyet Ölçeği arasında negatif ve orta düzeyde bir ilişki bulundu. Katılımcıların phubbing düzeylerinin orta düzeyde olduğu ve yaşam doyumlarının düşük olduğu belirlendi.

Sonuç: Phubbing ile yaşam doyumu arasında anlamlı bir ilișki bulundu. Hemşireler, covid-19 pandemi sürecinde telefon bağımlılığını önlemek için bireylere olumlu sağlık davranışları kazandırmalıdır.

Anahtar kelimeler: Phubbing, cep telefonu kullanımı, yaşam doyum, Türkiye

\section{Introduction}

People have turned to social media more to access information about both social life and the pandemic in Turkey due to mandatory restrictions in daily life after the COVID-19 pandemic (1).In crisis periods, such as the COVID-19 pandemic, the use of problematic technology having addiction properties increases significantly and it can turn into habits that are difficult to quit $(2,3)$. Since people use the smartphone more to cope with negative emotions caused by COVID-19, they have learned many features of smartphones during this period (4).

Phubbing is defined as focusing attention on smart phones while communicating with other people in a social environment, 
dealing with the smartphone by being indifferent to the environment instead of listening to other people, and avoiding their perceptions from interpersonal communication (5-7). Phubbing is a multidimensional disorder and social behavior disorder as it contains the types like internet, social media, and game addiction, beyond smartphone addiction due to the computer and internet access features of smart phones (8-10). Phubbing, which is conceptualized as a new type of addiction, causes the formation of new anxiety areas in individuals such as the fear of missing social developments, nomophobia, and netless phobia. Phubbing behaviors negatively affect the social development area as it breaks the communication and interaction link of the individual in a social environment (11). The studies have also shown that phubbing harms interpersonal communication $(12,13)$.

Life satisfaction is the cognitive expression of human happiness, and allows people to have a healthy, long, quality and meaningful life $(14,15)$. It is the cognitive evaluation made by the individual for his/her satisfaction or dissatisfaction towards his/her family, environment, friends, and his/her own life (14). Life satisfaction of many people has been negatively affected by the severity of COVID-19, the decrease in social interaction due to restrictions, fear, and geographical location (16). Satıcı et al., determined in their study that the COVID-19 fear was negatively correlated with psychological distress and life satisfaction (17).

People may exhibit behaviors like using social media or surfing the internet in order to relieve stress, anxiety and depressed mood experienced due to the COVID-19 pandemic. In this process, while technology provides the entertainment needed, it also becomes the main tool for socializing (2). In the literature, no study was found investigating the correlation between the phubbing and life satisfaction in individuals during the COVID-19 pandemic. For this reason, the aim of this study was to determine the correlation between phubbing and life satisfaction during the COVID-19 pandemic. We believed that the results of the present study would contribute to the literature.

In this study; answers were sought to questions such as what are the phubbing and life satisfaction levels of adult individuals, is there a difference between the sociodemographic characteristics of adults and their phubbing and life satisfaction levels, is there a relationship between phubbing and life satisfaction levels in adults.

\section{Methods}

\section{Sample}

The population of this descriptive study was composed of individuals over the age of 18 in Turkey. The number of individuals aged 18 and over in Turkey is 60,863,705. The sample size to represent the study population was determined according to the known sample calculation. The study population was calculated as 664 with 99\% confidence interval and 5\% margin of error. The study was carried out with 682 people who agreed to participate in the study between 15.02.2021 and 15.03.2021 by using the snowball sampling method, one of the improbable sampling methods. A total of 688 people were reached, but the survey of 6 people under the age of 18 were excluded from the study. People over the age of 18 , who could use social media and volunteered to participate in the research were included in the study.

\section{Procedure}

In order to minimize face-to-face interaction due to the pandemic, a digital questionnaire was prepared by the researchers. Survey forms were prepared via Google forms (URL:https://docs.google.com7forms/d/ e/1FAlpQLSfTSnSWCOFFsX wYhkxCIF0OqmJuRer3NvwUBSNj17z zhKYqQ/viewform? $\mathrm{vc}=0 \& \mathrm{c}=0 \& \mathrm{w}=1 \& \mathrm{fl} \mathrm{r}=0)$. Before starting the study, the questionnaire was tested electronically. It was announced on social media platforms that the study would be conducted and it was reported that participation in the study was on a voluntary basis. At the top of the questionnaire sent to the participants, there was information about the purpose and content of the study and that the participation in the study was based on voluntariness. The online link of the questionnaires was sent to the participants via social media tools (mail, Whatsapp, Instagram, Facebook). In order to conduct the study, approval was obtained from ethic (Ethic No: 2021/E.878). In addition, approval was obtained from the TR Ministry of Health Scientific Research Platform to conduct the research (Form no: 2021-01-03T20_32_50.xml). In the digitally prepared form, the purpose of the study was written and consent was obtained from the participants to participate in the study. At the top of the questionnaire, it was stated that participation in the research was on a voluntary basis and that those who want to participate must answer the questionnaire questions. The identity information of the participants was not recorded in the questionnaire. This study was conducted in accordance with the Principles of the Declaration of Helsinki.

\section{Measures}

"Personal Information Form, Phubbing Scale and Satisfaction with Life Scale" were used as the data collection tools. The questionnaire form structurally consisted of 3 screens (sections) and a total of 28 questions. The questions on the first screen consisted of questions containing the personal information of the participants, the questions on the second screen were aimed at measuring the phubbing levels of the individuals, and the third screen consisted of questions about measuring the life satisfaction of the participants. In the online form, individuals were only allowed to provide one response. In the study, it was 
obligatory to fill in each question in the questionnaire. People had a chance to come back. Data forms were collected by checking regularly. It took an average of 15 minutes to fill out the questionnaires.

\section{Personal information form}

There are a total of eight questions prepared by the researchers based on the literature and about socio-demographic and pandemic properties (age, gender, marital status, education, working status, income level, family type, state of coronavirus to affect interpersonal relationships).

\section{Phubbing Scale (PS)}

It was developed by Chotpitayasunondh and Douglas (2018) (18). Its Turkish validity and reliability were conducted by Ergünet al.,(2019) (19). The scale has 15 items and is 7-point Likert type. The scale is composed of four subscales(Nomophobia, Interpersonal Conflict, Self-isolation and Problem Acceptance). A high score on the scale indicates a high level of phubbing. The Cronbach's alpha internal consistency coefficients were calculated as 0.91 for the overall scale, 0.82 for the Nomophobia subscale, 0.84 for Interpersonal Conflict subscale, 0.86 for Self-isolation subscale, and 0.74 for the Problem Acceptance subscale (19). In this study, the Cronbach's alpha internal consistency coefficients were found as 0.95 for the overall scale, 0.90 for Nomophobia, 0.91 for interpersonal conflict, 0.94 for the self-isolation, and 0.80 for the problem acceptance subscales, respectively.

\section{Satisfaction with Life Scale (SLS)}

It is a 5-point Likert type scale with 5 items that was developed by Dieneret al.,(1985) (20). It is a measurement tool measuring the subjective well-being of the individual. It was adapted to Turkish by Dağlı and Baysal (2016) (21). The Cronbach's alpha internal consistency coefficient of the scale was calculated as 0.88 . While the low score is considered as low life satisfaction, the high score is accepted as an indicator of high life satisfaction. In this study, Cronbach's alpha internal consistency coefficient was found as 0.88 .

\section{Statistical Analysis}

The data were evaluated in SPSS 24.0 (Statistical Packet for Social Sciencesfor Windows) statistical program. In the statistical analysis, the suitability of the data to normal distribution was evaluated with the Kolmogorov Smirnov distribution test and the data were not suitable for normal distribution. As well as descriptive statistics (percentage, frequency, mean, standard deviation, minimum, maximum), in the evaluation of the data, Mann-Whitney $U$ tests were used to evaluate the significance of two independent variables, and Kruskal-Wallis tests were used to evaluate the significance of three or more independent variables. Spearman correlation analysis was used to measure the correlation between SLS and PS total and subscale scores. It was expressed for pearson correlation coefficients that values of $<0.2$ were very weak, values between 0.2-0.39 were weak, values between 0.4-0.69 were moderate, values between 0.7-0.89 were high and coefficients of $\geq 0.8$ refer to very high correlation (22). The Cronbach's alpha coefficient was calculated.

\section{Results}

It was determined that $35.9 \%$ of the participants were in the age range of $21-30$ years, $77.0 \%$ were female, $82.0 \%$ were single, $75.2 \%$ were $\geq$ University graduates, 66.6\% were unemployed, 48.5\% had an income equal to expenses, $88.0 \%$ had nuclear family and corona virus negatively affected interpersonal relationships of 94.7\% (Table 1).

It was found in the study that there was a significant difference between PS mean scores of the adult individuals participating in the study in terms of family type and the effect of corona virus on interpersonal relationships $(p<0.05)$. A significant difference was determined between the Nomophobia subscale mean scores in terms of age, marital status, education, and income status $(p<0.05)$. There was a significant difference between the Interpersonal conflict subscale mean scores in terms of age, marital status, education, working status and family type status $(p<0.05)$. A significant difference was determined between Self-isolation subscale mean scores according to marital status, education, working and the effect of corona virus on interpersonal relations $(p<0.05)$. A significant difference was determined between Problem Acceptance subscale mean scores in terms of age, income level and the effect of corona virus on interpersonal relationships $(p<0.05)$. There was a significant difference between SLS mean scores in terms of gender, education, income level and family type $(p<0.05)$ (Table 2$)$.

It was determined that PS total mean score was 50.69 \pm 15.18 , its subscales' mean scores were 16.24 \pm 5.21 for Nomophobia, 13.03 \pm 4.57 for Interpersonal Conflict, 11.39 \pm 5.37 for Selfisolation, 10.02 \pm 3.55 for Problem Acceptance and SLS mean score was $12.77 \pm 4.37$ (Table 3 ).

A negative and moderate correlation was found between the Phubbing Scale and Satisfaction with Life Scale ( $r=-0.505$, $p=0.000)$. In other words, as the cellphone usage increased, the life satisfaction level decreased. Phubbing Scale and its subscales had a negative correlation with Satisfaction with Life Scale (Table 4).

\section{Discussion}

It was determined that as the age of the participants decreased, their nomophobia level increased, nomophobia subscale mean score of the younger individuals was above the medium level. A negative and significant correlation was found between age 
Table 1: Distribution of the socio-demographic characteristics of the individuals $(n=682)$

\begin{tabular}{|c|c|c|c|}
\hline & & $\mathrm{n}$ & $\%$ \\
\hline \multirow{4}{*}{ Age } & Between $18-20$ years & 249 & 3.6 \\
\hline & Between 21-30 years & 245 & 35.9 \\
\hline & Between $31-40$ years & 11 & 16.3 \\
\hline & $\geq 41$ years & 77 & 11.3 \\
\hline \multirow{2}{*}{ Gender } & Female & 525 & 77.0 \\
\hline & Male & 157 & 23.0 \\
\hline \multirow{2}{*}{ Marital Status } & Single & 559 & 82.0 \\
\hline & Married & 123 & 18.0 \\
\hline \multirow{3}{*}{ Education Status } & $\leq$ Primary school & 54 & 7.9 \\
\hline & High school & 115 & 16.9 \\
\hline & $\geq$ University & 513 & 75.2 \\
\hline \multirow{2}{*}{ Working Status } & Yes & 228 & 33.4 \\
\hline & No & 454 & 66.6 \\
\hline \multirow{3}{*}{ Income status } & Income less than expenses & 294 & 43.1 \\
\hline & Income equal to expenses & 331 & 48.5 \\
\hline & Income more than expenses & 57 & 8.4 \\
\hline \multirow{2}{*}{ Family type } & Nuclear family & 600 & 88.0 \\
\hline & Extended family & 82 & 12.0 \\
\hline \multirow{4}{*}{$\begin{array}{l}\text { Corona virus affecting your } \\
\text { interpersonal relationships }\end{array}$} & Negative & 646 & 94.7 \\
\hline & Positive & 36 & 5.3 \\
\hline & Total & 682 & 100.0 \\
\hline & & \multicolumn{2}{|l|}{$\bar{X} \pm S D$} \\
\hline Mean age & & \multicolumn{2}{|l|}{$26.85 \pm 9.28$} \\
\hline
\end{tabular}

and nomophobia in the study by Erdemet al., (23), the smart phone addiction levels of 20 years old and younger individuals were determined to be higher than other people in the study by Kahyaoğlu et al., (24). In their study, Barrios-Borjaset al., (25) suggested that phubbing addiction increases the individual" desire to use smart phone, thus causing nomophobia. The result is similar to the literature. Due to the fact that young adults stay at home due to Covid 19, efforts to reach friends and socialize through the phone, young people's responsibilities less than adults and spending more time on the phone may have an impact on the result. COVID-19 pandemic and social isolation mostly affected adolescents and young adults and they caught up in social media use in particular from internet addiction, which is a behavioral addiction to reduce the strong shock of the pandemic (26).

It was determined that the interpersonal conflict subscale mean scores of the participants increased as their age decreased (Table 2). The fact that smart phone addiction of young individuals negatively affected their interpersonal relationships may be effective on the result. In the study by Yıldırım and Ozan (10) with university students, it was concluded that social media and smart phone addiction is a factor reducing communication in interpersonal relationships. In their study, Roberts and David (13) stated that smartphones affected all kinds of interpersonal relationships including romantic relationships. The result of the present study is similar to the literature. Since phubbing behavior causes conflicts, it damages the relationship by reducing the satisfaction in the relationship (27). Phubbing causes individuals to focus on their smartphones in social environments instead of communicating with their circle without knowing it and negatively affects their social communication (11).

It was determined that the mean scores of the younger individuals participating in the study from the problem acceptance subscale were higher than the other age groups (Table 2).Likewise, it was also stated in the study of Aagaard (28) that young people described phubbing behaviors as one that make them felt disrespectful, and worthless but they were inconsistent in exhibiting these behaviors. Since young people spend more time on the phone than adults, accessing more information about their harm in the electronic environment may affect the 
Table 2: Distribution of the individuals' socio-demographic characteristics and SLS and PS total and subscale mean scores

\begin{tabular}{|c|c|c|c|c|c|c|c|}
\hline & & Nomophobia & $\begin{array}{l}\text { Interpersonal } \\
\text { Conflict }\end{array}$ & Self-isolation & $\begin{array}{l}\text { Problem } \\
\text { Acceptance }\end{array}$ & PS total & SLS \\
\hline & & $\bar{X} \pm S D$ & $\overline{\mathrm{X}} \pm \mathrm{SD}$ & $\bar{X} \pm S D$ & $\bar{X} \pm S D$ & $\bar{X} \pm S D$ & $\bar{X} \pm S D$ \\
\hline \multirow{5}{*}{ Age } & Between 18-20 & $17.28 \pm 5.43$ & $13.81 \pm 5.47$ & $11.96 \pm 5.57$ & $10.65 \pm 4.09$ & $52.95 \pm 16.41$ & $13.26 \pm 4.80$ \\
\hline & Between 21-30 & $16.40 \pm 4.94$ & $13.46 \pm 2.36$ & $10.86 \pm 4.98$ & $10.00 \pm 3.13$ & $49.34 \pm 14.67$ & $12.75 \pm 4.24$ \\
\hline & Between 31-40 & $15.92 \pm 5.15$ & $13.04 \pm 4.80$ & $11.80 \pm 6.23$ & $9.54 \pm 3.39$ & $51.54 \pm 16.80$ & $12.00 \pm 3.99$ \\
\hline & $\geq 41$ & $12.80 \pm 3.83$ & $12.53 \pm 4.36$ & $10.70 \pm 4.31$ & $9.50 \pm 2.29$ & $46.48 \pm 6.62$ & $12.33 \pm 3.64$ \\
\hline & Significance* $^{*}$ & $p=0.001$ & $p=0.003$ & $p=0.110$ & $p=0.016$ & $p=0.114$ & $p=0.250$ \\
\hline \multirow{3}{*}{ Gender } & Female & $16.38 \pm 5.25$ & $13.01 \pm 5.47$ & $11.38 \pm 4.47$ & $10.11 \pm 3.64$ & $50.89 \pm 15.24$ & $13.14 \pm 4.37$ \\
\hline & Male & $15.77 \pm 5.07$ & $13.10 \pm 4.45$ & $11.43 \pm 5.02$ & $9.70 \pm 3.22$ & $50.03 \pm 15.01$ & $11.50 \pm 4.13$ \\
\hline & Significance $^{* *}$ & $p=0.285$ & $p=0.926$ & $p=0.630$ & $p=0.412$ & $p=0.412$ & $p=0.001$ \\
\hline \multirow{3}{*}{ Marital Status } & Single & $16.74 \pm 5.21$ & $13.22 \pm 3.05$ & $11.65 \pm 5.54$ & $9.39 \pm 2.24$ & $46.80 \pm 9.32$ & $12.04 \pm 3.82$ \\
\hline & Married & $13.95 \pm 4.60$ & $12.99 \pm 4.84$ & $10.22 \pm 5.35$ & $10.15 \pm 3.77$ & $51.55 \pm 16.06$ & $12.93 \pm 4.47$ \\
\hline & Significance $^{* *}$ & $p=0.001$ & $p=0.006$ & $p=0.013$ & $p=0.410$ & $p=0.153$ & $p=0.158$ \\
\hline \multirow{4}{*}{ Education level } & $\leq$ Primary school & $12.33 \pm 2.67$ & $13.46 \pm 2.54$ & $11.55 \pm 5.51$ & $8.90 \pm 2.72$ & $44.35 \pm 4.53$ & $9.44 \pm 3.60$ \\
\hline & High school & $16.77 \pm 5.28$ & $13.25 \pm 3.54$ & $11.52 \pm 5.16$ & $9.77 \pm 2.73$ & $50.24 \pm 12.60$ & $11.84 \pm 4.45$ \\
\hline & $\geq$ University & $15.69 \pm 4.99$ & $12.94 \pm 4.98$ & $9.64 \pm 4.06$ & $10.19 \pm 3.77$ & $51.46 \pm 16.25$ & $13.32 \pm 4.24$ \\
\hline & Significance* & $p=0.001$ & $p=0.005$ & $p=0.016$ & $p=0.068$ & $p=0.121$ & $p=0.001$ \\
\hline \multirow{3}{*}{ Working status } & Yes & $15.58 \pm 5.12$ & $12.79 \pm 4.34$ & $11.95 \pm 5.59$ & $9.64 \pm 3.19$ & $50.70 \pm 15.90$ & $12.85 \pm 4.19$ \\
\hline & No & $16.57 \pm 5.23$ & $13.51 \pm 4.97$ & $11.12 \pm 5.23$ & $10.20 \pm 3.71$ & $50.69 \pm 14.82$ & $12.72 \pm 4.46$ \\
\hline & Significance $^{* *}$ & $p=0.064$ & $p=0.009$ & $p=0.031$ & $p=0.145$ & $p=0.360$ & $p=0.260$ \\
\hline \multirow{4}{*}{ Income status } & $\begin{array}{l}\text { Income less than } \\
\text { expenses }\end{array}$ & $15.94 \pm 5.61$ & $12.61 \pm 3.91$ & $10.91 \pm 4.93$ & $9.76 \pm 3.58$ & $49.24 \pm 13.95$ & $10.42 \pm 3.17$ \\
\hline & $\begin{array}{l}\text { Income equal to } \\
\text { expenses }\end{array}$ & $16.26 \pm 4.84$ & $13.26 \pm 5.09$ & $11.74 \pm 5.68$ & $10.27 \pm 3.57$ & $51.54 \pm 16.06$ & $14.61 \pm 4.17$ \\
\hline & $\begin{array}{l}\text { Income more than } \\
\text { expenses }\end{array}$ & $17.66 \pm 5.02$ & $13.85 \pm 4.34$ & $11.89 \pm 5.55$ & $9.85 \pm 3.25$ & $53.28 \pm 15.50$ & $14.15 \pm 5.07$ \\
\hline & Significance* $^{*}$ & $p=0.038$ & $p=0.134$ & $p=0.560$ & $p=0.044$ & $p=0.216$ & $p=0.001$ \\
\hline \multirow{3}{*}{ Family type } & Nuclear family & $16.12 \pm 5.19$ & $13.16 \pm 4.50$ & $11.43 \pm 5.21$ & $10.02 \pm 3.41$ & $50.74 \pm 14.64$ & $12.89 \pm 4.34$ \\
\hline & Extended family & $17.10 \pm 5.32$ & $12.07 \pm 4.98$ & $11.14 \pm 6.46$ & $10.02 \pm 4.50$ & $50.35 \pm 18.74$ & $11.87 \pm 4.49$ \\
\hline & Significance $^{* *}$ & $p=0.100$ & $p=0.005$ & $p=0.051$ & $p=0.169$ & $p=0.039$ & $p=0.028$ \\
\hline \multirow{3}{*}{$\begin{array}{l}\text { The effect of } \\
\text { corona virus on } \\
\text { interpersonal } \\
\text { relationships }\end{array}$} & Negative & $16.21 \pm 5.09$ & $12.92 \pm 4.45$ & $15.75 \pm 7.52$ & $9.84 \pm 3.48$ & $60.72 \pm 20.91$ & $12.80 \pm 4.32$ \\
\hline & Positive & $16.83 \pm 7.09$ & $15.02 \pm 6.09$ & $11.15 \pm 5.12$ & $13.11 \pm 3.49$ & $50.14 \pm 15.61$ & $12.13 \pm 5.16$ \\
\hline & Significance $^{* *}$ & $p=0.734$ & $p=0.078$ & $p=0.001$ & $p=0.001$ & $p=0.001$ & $p=0.105$ \\
\hline
\end{tabular}

Table 3. Distribution of SLS and PS total and subscale mean scores and minimum - maximum values

\begin{tabular}{|l|l|l|l|} 
& $\overline{\mathbf{X}}$ & SD & Received minimum-maximum \\
\hline PS total & 50.69 & 15.18 & $31-101$ \\
\hline Nomophobia & 16.24 & 5.21 & $8-28$ \\
\hline Interpersonal conflict & 13.03 & 4.57 & $6-28$ \\
\hline Self-isolation & 11.39 & 5.37 & $6-28$ \\
\hline Problem acceptance & 10.02 & 3.55 & $4-21$ \\
\hline SLS & 12.77 & 4.37 & $5-25$ \\
\hline PS: Phubbing scale, SLS: Satisfaction of life scale & & & \\
\hline
\end{tabular}


Table 4: Correlation distribution ofSLS and PS total and subscales

\begin{tabular}{|c|c|c|c|c|c|c|}
\hline & & 1 & 2 & 3 & 4 & 5 \\
\hline 2 Nomophobia & $\begin{array}{l}r \\
p\end{array}$ & $\begin{array}{l}0.740 \\
\mathbf{0 . 0 0 0}\end{array}$ & & & & \\
\hline 3 Interpersonal Conflict & $\begin{array}{l}r \\
p\end{array}$ & $\begin{array}{l}0.809 \\
\mathbf{0 . 0 0 0}\end{array}$ & $\begin{array}{l}0.392 \\
\mathbf{0 . 0 0 0}\end{array}$ & & & \\
\hline 4 Self-isolation & $\begin{array}{l}r \\
p\end{array}$ & $\begin{array}{l}0.870 \\
\mathbf{0 . 0 0 0}\end{array}$ & $\begin{array}{l}0.419 \\
\mathbf{0 . 0 0 0}\end{array}$ & $\begin{array}{l}0.702 \\
\mathbf{0 . 0 0 0}\end{array}$ & & \\
\hline 5 Problem Acceptance & $\begin{array}{l}r \\
p\end{array}$ & $\begin{array}{l}0.828 \\
\mathbf{0 . 0 0 0}\end{array}$ & $\begin{array}{l}0.555 \\
\mathbf{0 . 0 0 0}\end{array}$ & $\begin{array}{l}0.533 \\
\mathbf{0 . 0 0 0}\end{array}$ & $\begin{array}{l}0.685 \\
\mathbf{0 . 0 0 0}\end{array}$ & \\
\hline $6 \mathrm{SLS}$ & $\begin{array}{l}r \\
p\end{array}$ & $\begin{array}{l}-0.505 \\
\mathbf{0 . 0 0 0}\end{array}$ & $\begin{array}{l}-0.404 \\
\mathbf{0 . 0 0 0}\end{array}$ & $\begin{array}{l}-0.307 \\
\mathbf{0 . 0 0 0}\end{array}$ & $\begin{array}{l}-0.315 \\
\mathbf{0 . 0 0 0}\end{array}$ & $\begin{array}{l}-0.217 \\
\mathbf{0 . 0 0 0}\end{array}$ \\
\hline
\end{tabular}

result. The fact that individuals continue phubbing behaviors unconsciously although they describe phubbing behaviors as attitudes that make them feel disrespectful, and worthless indicates how negative the situation has become (11).

It was determined that the interpersonal conflict subscale scores of the individuals having nuclear family structure from those participating in the study were higher (Table 2). The studies indicated that phubbing negatively affected the relationship, marital satisfaction, and in-family communication of married individuals. Phubbing behaviors negatively affected the relationship between couples in the study by Roberts and David (13); whereas, couples with high phubbing behaviors had higher stress, anxiety, and depression levels and their psychological well-being levels were lower in the study by González-Riveraet al., (29). The result of the present study is similar to the literature. Due to the low number of members in the family, the low communication of individuals with each other may affect the result of not being able to find solutions to each other's problems due to spending too much time on the phone.

It was determined that individuals whose interpersonal relations were negatively affected by coronavirus had higher self-isolation, and problem acceptance subscale mean scores than individuals whose interpersonal relationships were not affected negatively, and their phubbing total mean scores were above moderate level (Table 2). The fact that the individuals in the study consider spending time on the phone as the savior to cope with many situations such as financial problems and negative mood caused by the pandemic, their fear of the COVID-19, quarantine, high amount of time spent at home, and wanting to follow the developments related to the pandemic may cause phubbing behaviors. Therefore, this situation can cause individuals to isolate themselves from other people around them, and damage their interpersonal relationships. The fact that the individuals in the study continue to show phubbing behaviors although they see those behaviors as a problem shows the dimension of this addiction. With the measures such as quarantine, isolation, and social distance applied because of theCOVID-19 pandemic, the time people spend at home increases and their daily routines are lost. As a result, many psychiatric problems such as future anxiety, phobia, depression, anger, loneliness, and behavioral addictions can occur in individuals and family members experiencing the pandemic $(2,28)$. People may exhibit phubbing behaviors because of the anxiety of missing the developments, and updates in the internet environments, social media and other sharing applications in the community (25).

In the study, a negative and moderate correlation was determined between the phubbing and life satisfaction (Table 4). Participants disconnected from social life due to excessive use of mobile phones which decreased family, and interpersonal communication and increased the conflicts and thus it may cause their life satisfaction to decrease. The main determinant of phubbing addiction is intense smartphone use (11). As a result of problematic smartphone use, technology use impairs life satisfaction (30). In their study, Prasadet al., stated that excessive use of smartphones had a negative effect on psychological wellbeing especially in young individuals and students (31). In the study of Blachnioet al., (32) conducted with Facebook users in different age groups, they determined that there was a negative correlation between Facebook addiction and life satisfaction. It was determined in the study by Pittman and Reich (33) that the loneliness level increased and happiness and life satisfaction of people decreased as the Facebook usage time increased. In the study conducted by Yukay (34) et al., with young adults, they determined that the social media addiction decreased life satisfaction, it was also determined in the study by Köse (35) that internet addiction decreased life satisfaction in adolescents. The result of the present study is similar to the literature. Individuals 
who do not have life satisfaction try to find the joy, which they cannot get from social environments, from the virtual world. Excessive phone usage in this situation keeps people away from real social life and causes behavioral problems to arise (36).

The fact that the study was conducted in a certain time period, the difficulty of reaching the participants due to the pandemic, the fact that the data were collected in electronic environment and illiterate people were not included in the study, and the answers given to the questionnaires were based on the notifications of the individuals is among the limitations of the study.

In this study, it was determined that the phubbing levels of adult individuals were moderate and their life satisfaction was at a low level. A negative and significant correlation was found between phubbing and life satisfaction. In other words, it was determined that the life satisfaction level decreased as cellphone usage increased. Changing time brings many innovations with it.

As a result of continuously developing technology, phones have become a part of our lives. The telephone has become an indispensable part of human life today. When this device which makes our lives easier, faster, and more fun, is not used appropriately, it is inevitable to have some problems. Considering that phone addiction can become more widespread with the increasing technological developments, it decreases the quality of life of individuals by interrupting social activities and interpersonal relations. In this respect, technology literacy training and awareness studies are needed.

\section{References}

1. Çerçi ÜÖ, Canöz N, Canöz K. Covid-19 krizi döneminde bilgilenme aracı olarak sosyal medya kullanımı. Selçuk Üniversitesi Sosyal Bilimler Enstitüsü Dergisi 2020; 44: 184-198.

2. Göker ME, Turan \$̦. COVID-19 pandemisi sürecinde problemli teknoloji kullanımı. ESTÜDAM Halk Sağ|ı̆̆ı Dergisi 2020; 5(COVID-19 Özel Sayısı): 108114.

3. Király O, Potenza MN, Stein DJ, et al. Preventing problematic internet use during the COVID-19 pandemic: Consensus guidance. Compr Psychiatry. 2020; 100: 152180 .

4. Elhai JD, Yanga H, McKayd D, Asmundsone GJG. COVID-19 anxiety symptoms associated with problematic smartphone use severity in Chinese adults. J Affect Disord. 2020; 274: 576-582.

5. Koca EB. Akıllı telefon bağımlılı̆ı ve sosyotelizm üzerine bir yazın taraması. Avrasya Sosyal ve Ekonomi Araştırmaları Dergisi 2019; 6(6): 399-411.

6. Cizmeci E. Disconnected, though satisfied: Phubbing behavior and relationship satisfaction. The Turkish Online Journal of Design, Art and Communication 2017; 7(2): 364-375.

7. Oberst U, Wegmann E, Stodt B, et al. Negative consequences from heavy social networking in adolescents: The mediating role of fear of missing out. J Adolesc 2017; 55: 51-60.

8. Ivanova A, Gorbaniuk O, Błachnio A, et al. Mobile phone addiction, phubbing, and depression among men and women: A moderated mediation analysis. Psychiatr Q 2020; 91(3): 655-668.
9. Göksün OD. Sosyotelist olma ve sosyotelizme maruz kalma ölçeklerinin Türkçeye uyarlanması. Afyon Kocatepe Üniversitesi Sosyal Bilimler Enstitüsü Dergisi 2018; 21(3): 657-671.

10. Yıldırım 0, Ünalan D. Dijital yerlilerin sosyotelizm (phubbing) eğilimlerinin değerlendirilmesi. Gümüșhane Üniversitesi İletişim Fakültesi Elektronik Dergisi 2020; 8(1): 276-297.

11. .Yam FC, IIlhan T. Holistic technological addiction of modern age: Phubbing. Psikiyatride Güncel Yaklașımlar 2020; 12(1): 1-15.

12. Wang $X$, Xie $X$, Wang $Y$, et al. Partner phubbing and depression among married chinese adults: The roles of relationship satisfaction and relationship length. Pers Individ Diff 2017; 110: 12-17.

13. Roberts JA, David ME. My life has become a major distraction from my cell phone: partner phubbing and relationship satisfaction among romantic partners. Comput Human Behav. 2016; 54: 134-141.

14. Taşlıyan M, Hırlak B, Güler B, et al. İnternet bağımlılı̆ı, yaşam doyumu ve bazı demografik değișkenler arasındaki ilișkiler. Osmaniye Korkut Ata University Journal of Economics and Administrative Sciences 2018; 2(2): 166-179.

15. Ata Z, Ekinci N. Yaşıı bireylerde yaşam doyumu: İzmir'de bir sağlıklı yaş alma merkezi örneği. İzmir Kâtip Çelebi Üniversitesi İktisadi ve İdari Bilimler Fakültesi Dergisi 2020; 3(1): 1-16.

16. Krause AE, Dimmock J, Rebar AL, et al. Music listening predicted improved life satisfaction in university students during early stages of the COVID-19 pandemic. Front Psychol. 2021; 11: 631033.

17. Satici B, Gocet-Tekin E, Deniz ME, et al. Adaptation of the fear of COVID-19 Scale: Its association with psychological distress and life satisfaction in Turkey. Int J Ment Health Addict 2020; doi: 10.1007/s11469-020-00294-0. .

18. Chotpitayasunondh V, Douglas KM. Measuring phone snubbing behavior: Development and validation of the Generic Scale of Phubbing (GSP) and the generic scale of being phubbed (GSBP). Comput Human Behav. 2018; 88: 5-17.

19. Ergün N, Göksu I, Sakız H. Effects of phubbing: Relationships with psychodemographic variables. Psychol Rep 2020; 123(5): 1578-1613.

20. Diener E, Emmons RA, Larson RJ, et al. The satisfaction with life scale. J Pers Assess. 1985: 49: 71-75.

21. Dağlı A, Baysal N. Yașam doyumu ölçeğinin Türkçe'ye uyarlanması: Geçerlik ve güvenirlik çalıșması. Elektronik Sosyal Bilimler Dergisi 2016; 15(59): 12501263.

22. Öztuna D, Elhan AH, Kurșun N. Sağlık araștırmalarında kullanılan ilișki katsayıları. Turkiye Klinikleri J Med Sci. 2008; 28: 160-165.

23. Erdem H. Türen U, Kalkın G. Mobil telefon yoksunluğu korkusu (nomofobi) yayılımı: Türkiye'den üniversite öğrencileri ve kamu çalıșanları örneklemi. Bilișim Teknolojileri Dergisi 2017; 10(1): 1-12.

24. Kahyaoglu H, Kurt S, Uzal Ö, et al. Sağlık Bilimleri Fakültesi öğrencilerinin akıllı telefon bağımlılık düzeylerinin sosyal ve eğitim hayatına etkisi. Eurasian Journal of Family Medicine 2016; 5(1): 13-19.

25. Barrios-Borjas DA, Bejar-Ramos VA, Cauchos-Mora VS. Excessive use of smartphones/cellphones: Phubbing and nomofobia. Rev Chil Neuropsiquiatr 2017; 55(3): 205-206

26. Dubey MJ, Ghosh R, Chatterjee S, et al. COVID-19 and addiction. Diabetes Metab Syndr. 2020; 14(5): 817-23.

27. Nazir T, Pișkin, M. Phubbing: A technological invasion which connected the world but disconnected humans. International Journal of Indian Psychology 2016; 3(4): 175-182

28. .Aagaard J. Digital akrasia: A qualitative study of phubbing. Al \& Society 2019; 35: 237-244. 
29. González-Rivera JA, Hernández-Gato I. Conflicts in romantic relationships over Facebook use: Validation and psychometric study. Behav Sci. 2019; 9(2): 18.

30. McDaniel BT, Coyne SM. "Technoference": The interference of technology in couple relationships and implications for women's personal and relational well-being. Psychol Pop Media Cult. 2016; 5(1): 85-98.

31. Prasad M, Patthi B, Singla A, et al. Nomophobia: A cross-sectional study to assess mobile phone usage among dental students. J Clin Diagn Res. 2017; 11(2): 34-39.

32. Blachnio A, Przepiorka A, Pantic I. Association between Facebook addiction, self-esteem and life satisfaction: A cross-sectional study. Comput Human Behav. 2016; 55: 701-705.
33. Pittman M, Reich B. Social media and loneliness: Why an Instagram picture may be worth more than a thousand Twitter words. Comput Human Behav. 2016; 62: 155-167.

34. Yukay YM, Çini A, Yasak B. Genç yetișkinlerde sosyal medya bă̆ımlılı̆̆ı, yalnızık ve yaşam doyumunun incelenmesi. Atatürk Üniversitesi Kazım Karabekir Eğitim Fakültesi Dergisi 2020; 40: 66-85.

35. Köse N. Ergenlerde internet bağımlılığının yaşam doyumuna etkisi. Elektronik Mesleki Gelișim ve Araștırmalar Dergisi 2016; (1):15-23.

36. Parmaksız I. İletișimde ve ilișkilerde phubbing. Türkiye Sosyal Araştırmalar Dergisi 2020; 24(2): 359-372. 